\title{
REVIEW
}

\section{Limits to top-down control of phytoplankton by oysters in Chesapeake Bay}

\author{
Lawrence R. Pomeroy ${ }^{1, *}$, Christopher F. D'Elia ${ }^{2}$, Linda C. Schaffner ${ }^{3}$ \\ ${ }^{1}$ Institute of Ecology, University of Georgia, Athens, Georgia 30602-2202, USA \\ ${ }^{2}$ Center for Science and Policy Applications for the Coastal Environment, University of South Florida, 140 7th Avenue S, \\ St. Petersburg, Florida 33701-5016, USA \\ ${ }^{3}$ Department of Biological Science, School of Marine Science, Virginia Institute of Marine Science, \\ College of William and Mary, Gloucester Point, Virginia 23062, USA
}

\begin{abstract}
Restoration of the oyster Crassostrea virginica population in Chesapeake Bay is often advocated as an easy solution for controlling phytoplankton blooms. Even at their pre-colonial densities, oysters are unlikely to have controlled blooms, despite the fact that sediment cores suggest that pre-colonial spring blooms were smaller than at present. Lack of access to all bay water and low springtime filtration rates would make it impossible for oysters to control the spring bloom and the resulting summer hypoxia. Previous studies have overestimated potential oyster filtration rates, because they extrapolated summer rates to spring conditions that are $20^{\circ} \mathrm{C}$ cooler. Previous studies have also assumed that oysters have access to all phytoplankton, without considering the spatial separation. In Chesapeake Bay, oysters and the spring bloom are separated horizontally owing to the size of the bay and its small tidal amplitude. Indeed, a multi-species guild of suspension feeders now present in the bay should have a filtration capacity approaching that of pre-colonial oysters, but it does not control the bloom. Actual oyster filtration potential must be lower than many advocates of oyster restoration assume, and replenishing the bay with oysters is not the means of controlling blooms and hypoxia.
\end{abstract}

KEY WORDS: Chesapeake Bay $\cdot$ Hypoxia $\cdot$ Oysters $\cdot$ Eutrophication

Resale or republication not permitted without written consent of the publisher

\section{INTRODUCTION}

Chesapeake Bay provides a richly documented case study of the limits to the control of phytoplankton by filter-feeding benthos in estuaries. Overfishing for more than a century and exotic parasitic diseases introduced $50 \mathrm{yr}$ ago have reduced the population of the native oyster Crassostrea virginica to a small fraction of its original size. In addition, during the last $50 \mathrm{yr}$, extensive spring phytoplankton blooms followed by summer hypoxia have become an increasingly serious problem. Extrapolating from individual filtering rates to the number of oysters he estimated to have been present in Chesapeake Bay in pre-colonial times, Newell (1988) estimated that the oyster population would then have cleared a volume of water equal to that of the bay in 2 to
$4 \mathrm{~d}$, and argued that filtration by oysters provided a significant control of blooms. He further suggested that restoration of the oyster population would control spring phytoplankton blooms. On the basis of Newell's (1998) calculation, oysters in Chesapeake Bay have been described as a lost keystone species that could prevent the hypoxia resulting from microbial utilization of phytoplankton not otherwise consumed (Jackson et al. 2001). Ruesink et al. (2005) repeated and accepted Newell's (1998) hypothesis, and Kemp et al. (2005), while emphasizing the overriding effect of anthropogenic sources of eutrophication, nonetheless gave credence to the Newell hypothesis.

Because diseases and accumulation of sediment on oyster beds have frustrated most efforts to rebuild native oyster populations in Chesapeake Bay, intro- 
duction of the non-native oyster species Crassostrea ariakensis, with putatatively higher resistance to disease, has been widely advocated to replace the native oyster, based on the assumption that this species will thrive, restore the oyster-fishing industry, and solve 'the phytoplankton bloom problem'. Although caution would seem to have been recommended in a recent study by the Ocean Studies Board, National Research Council (2004), even that report has been cited as advocating introduction of an exotic oyster species into Chesapeake Bay to control blooms and the resultant hypoxia (Ruesink et al. 2005). We examine the Newell hypothesis in terms of the hydrography, past and present, of Chesapeake Bay, and the potential role of the present oyster population relative to that of the suspension-feeding guild as a whole.

\section{Spatial limits to bloom control}

Control of phytoplankton by oysters requires that the oysters have access to all the spring bloom biomass at the time it is developing and that they remove phytoplankton at a rate that equals or exceeds their growth rate. Control of blooms is thus only effective if removal rate exceeds the rate of phytoplankton production. In a graphical presentation of clearance time by molluscs versus residence time of estuarine water, Smaal \& Prins (1993) made such a calculation for many estuaries including the Chesapeake Bay. The relationship, as they presented it, is valid where the water is well mixed in the short term, as for example in the freshwater reaches of the Potomac River, where Cohen et al. (1984) showed that the introduced bivalve Corbicula fluminea cleared the water of phytoplankton. However, not all estuaries are well mixed or rapidly mixed (Monbet 1992). When mixing by wind and tidal currents is not complete in either the vertical or horizontal axis, benthic suspension feeders will not have access to all water in the short term, phytoplankton will reproduce until nutrient limited, and the simple calculation will fail. Even relatively small, shallow estuaries sometimes are not fully mixed in the short term (e.g. Loo \& Rosenberg 1989, Hily 1991). Cloern's (1982) study of shallow South San Francisco Bay showed that stratification of the water column, isolating the upper layer in which phytoplankton grow from the filter-feeding benthos, limits the ability of suspension feeders to control phytoplankton. Although molluscs in San Francisco Bay control phytoplankton most of the time, blooms occur when stratification by river water coincides with neap tides (Jassby et al. 1996).

Although the effects of stratification in limiting access of benthic suspension feeders to phytoplankton are widespread (Cloern 1996), stratification is only a partial limit in Chesapeake Bay, because some oyster beds are, or were, within the upper mixed layer and would have potential access to the bloom. However, because of its large size and small tidal amplitude, lateral circulation of water in the main stem of the bay, where spring blooms develop, limits access of suspension feeders to phytoplankton. Gerritsen et al. (1994) developed a model of water movement for Chesapeake Bay, taking into account the lateral movement of water between the main stem, its margins, and the tributaries. Simulating clearance rates by the existing biomass of species of suspension-feeding molluscs, including the remaining oysters, the model predicts that all the present mollusc populations, even without the former oyster reefs, potentially control or significantly affect phytoplankton along the sides of the main stem and in most tributaries. However, molluscs cannot filter the water in the main stem over a time period short enough to control phytoplankton. Since that is where the core of the spring bloom develops, control in the main stem is essential.

The results of Gerittsen et al.'s (1994) simulation are supported by empirical findings of Malone et al. (1986), which indicate that less than half the spring bloom is removed by all the extant grazers, including zooplankton and menhaden. Gerritsen et al.'s (1994) model predicts that the pre-colonial oyster reefs, situated along the margins in the same shallow parts of the bay as most present mollusc populations, would not have had sufficient access to all water in the main stem of the bay to control spring blooms (Fig. 1). Chesapeake Bay has a small tidal amplitude, typically $<1 \mathrm{~m}$, and its central main stem is 5 to $18 \mathrm{~km}$ in width. Even though precolonial oyster reefs were partially in the upper mixed layer, the main stem of the bay was (and is) too large and lateral water exchange too limited to permit control of spring phytoplankton production by organisms along the shoals. Gerritsen et al.'s (1994) model also implies that the assumption of short-term access by oysters to all bay water limits interpretations based on the 1dimensional model of Ulanowicz \& Tuttle (1992). Because events are not the same under each square meter of the Chesapeake Bay, a model of 1 representative square meter of the bay misses the disconnection occurring in the horizontal axes. The horizontal spatial disconnection between oysters and phytoplankton blooms in the main stem of the bay would by itself seem to place top-down control of spring phytoplankton in doubt, but additional limitations need to be addressed.

\section{Seasonal temperature limits}

Newell's (1988) calculation of the effect of oysters was based on a summer filtration rate for oysters. 


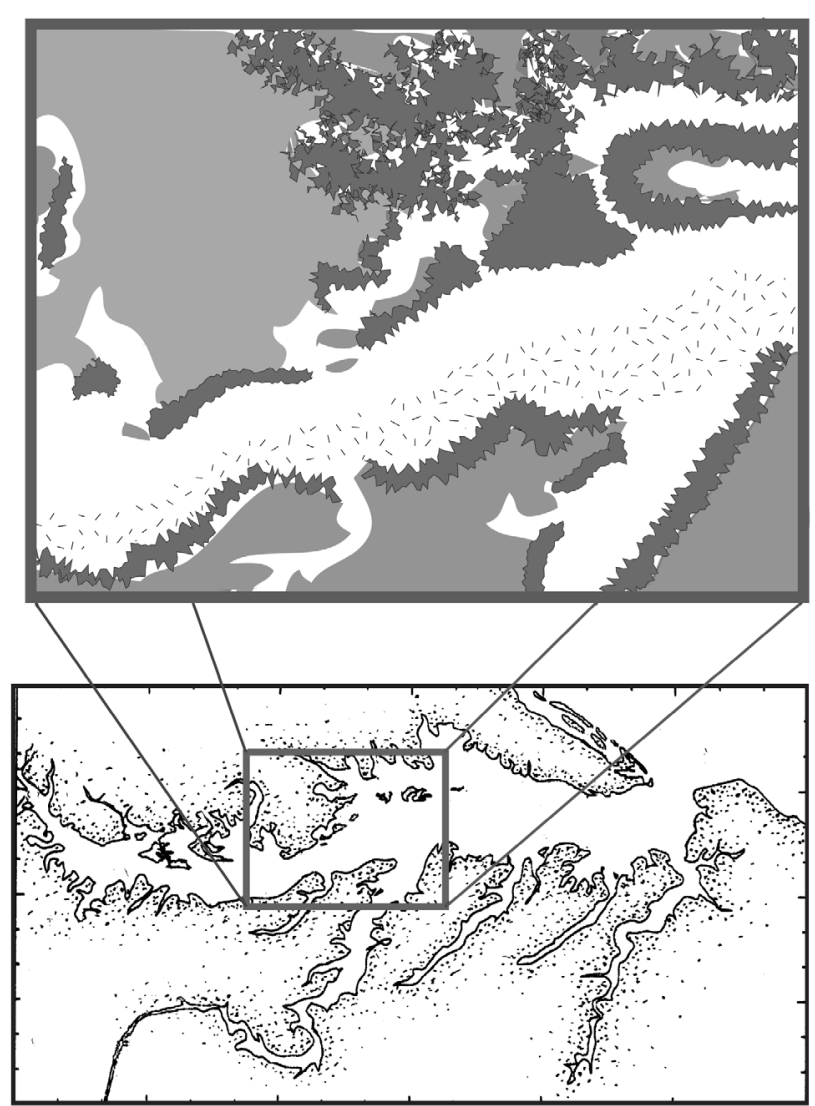

Fig. 1. Crassostrea virginica. Spatial separation of principal mass of oysters (darker gray) in central Chesapeake Bay, between the mouths of the Choptank and Potomac rivers, on 1893 navigation chart (Paynter 2003) (at a time when original oyster reefs were still intact) from the active core of a major spring diatom bloom (stippled) in central Chesapeake Bay during the high runoff year 1996 (Hood \& Boicourt 2005). Year-to-year variation occurs, but this should be typical of separation in space of blooms and oysters

Since the diatom bloom that causes summer hypoxia usually begins in March, or even late February (Hagy et al. 2005), it is then that control by filter-feeding organisms must suppress the bloom. The appropriate filtration rate to apply to the calculation is that for March. The March filtration rate of oysters used by Newell et al. (2005) to estimate seasonal biodeposition is 1 order of magnitude lower than the summer rate used in Newell's (1998) original calculation (0.45 vs. $5 \mathrm{l} \mathrm{h}^{-1} \mathrm{~g}^{-1}$ ). Repeating Newell's (1988) calculation using this later estimate of the spring filtration rate suggests that at the time of year when control of the spring bloom could occur, the estimated pre-colonial oyster population would have required some tens of days - more than the doubling time of the bloom - to filter the volume of the bay if, in fact, it had access to all the water (Table 1).
Temperature effects on filtration rates are, however, complex and have been debated extensively. Laboratory experiments have shown a linear response to acute temperature change, but have also shown acclimation to temperature change over periods of $2 \mathrm{wk}$ or more (Widdows \& Bayne 1971). It should be noted, however, that the experiments of Widdows \& Bayne (1971) were over a limited range of temperature. Eastern North America experiences a wider range of seasonal temperature changes than does Western Europe. In the original work on clearance rates of oysters in Long Island Sound over a temperature range of 0 to $39^{\circ} \mathrm{C}$, Loosanoff (1958) found empirically that many oysters were closed or not pumping at temperatures below $10^{\circ} \mathrm{C}$ and that most pumping ceased below $5^{\circ} \mathrm{C}$. Between 16 and $32^{\circ} \mathrm{C}$, all oysters pumped at rates that increased with increasing temperature, with rates declining at still higher temperatures $\left(>32^{\circ} \mathrm{C}\right)$. Jørgensen et al. (1990) critically reviewed the extensive work that has since been done on the mollusc pump, concluding that it is 'a viscous, leaky, constant-force pump' that processes water autonomously. However, the outcome resulting from variations in valve gape and water viscosity seems to be a quasi-linear positive relation to temperature vs. clearance rate in Fig. 2 (Jørgensen et al. 1990).

Since early spring water temperature in Chesapeake Bay is 5 to $7^{\circ} \mathrm{C}$, clearance rates may be expected to be low at that time. The rates reported by Newell et al. (2005) are those of in situ acclimated oysters measured by Jordan (1987). Similar low spring rates might be expected for the entire suspension-feeding guild. Hagy et al. (2005) report little bioturbation of sediments in March; as a surrogate measure of activity of infauna, this suggests reduced filtration by the infauna. Newell's (1988) original summer filtration rate was also used uncritically in the Gerritsen et al. (1994) model, which found a limited effect of molluscs on the spring bloom. If a lower filtration rate applies in spring, the model should predict even less effect.

Table 1. Crassostrea virginica. Comparison of the time required to filter the upper $9 \mathrm{~m}$ of Chesapeake Bay as a whole assuming a summer filtering rate of $5 \mathrm{l} \mathrm{g}^{-1} \mathrm{~h}^{-1}$ (assumptions, dimensions and rates of Newell 1988) with time required assuming a spring filtering rate of $0.45 \mathrm{l} \mathrm{g}^{-1} \mathrm{~h}^{-1}$ (Newell et al. 2005). This comparison does not address the issue of mixing rate of bay water and potential access of suspension feeders to all bay water. Oyster biomass was $1.88 \times 10^{11} \mathrm{~g}$

\begin{tabular}{|llcc|}
\hline $\mathrm{l} \mathrm{g}^{-1} \mathrm{~h}^{-1}$ & $\begin{array}{c}\mathrm{m}^{3} \mathrm{~d}^{-1} \\
\text { filtered }\end{array}$ & $\mathrm{m}^{3} \mathrm{~d}^{-1} \mathrm{~m}^{2}$ & $\begin{array}{c}\text { Days to } \\
\text { filter } 9 \mathrm{~m}\end{array}$ \\
\hline 5 & $2.3 \times 10^{10}$ & 2.1 & 4 \\
0.45 & $2.0 \times 10^{9}$ & 0.18 & 34 \\
\hline
\end{tabular}



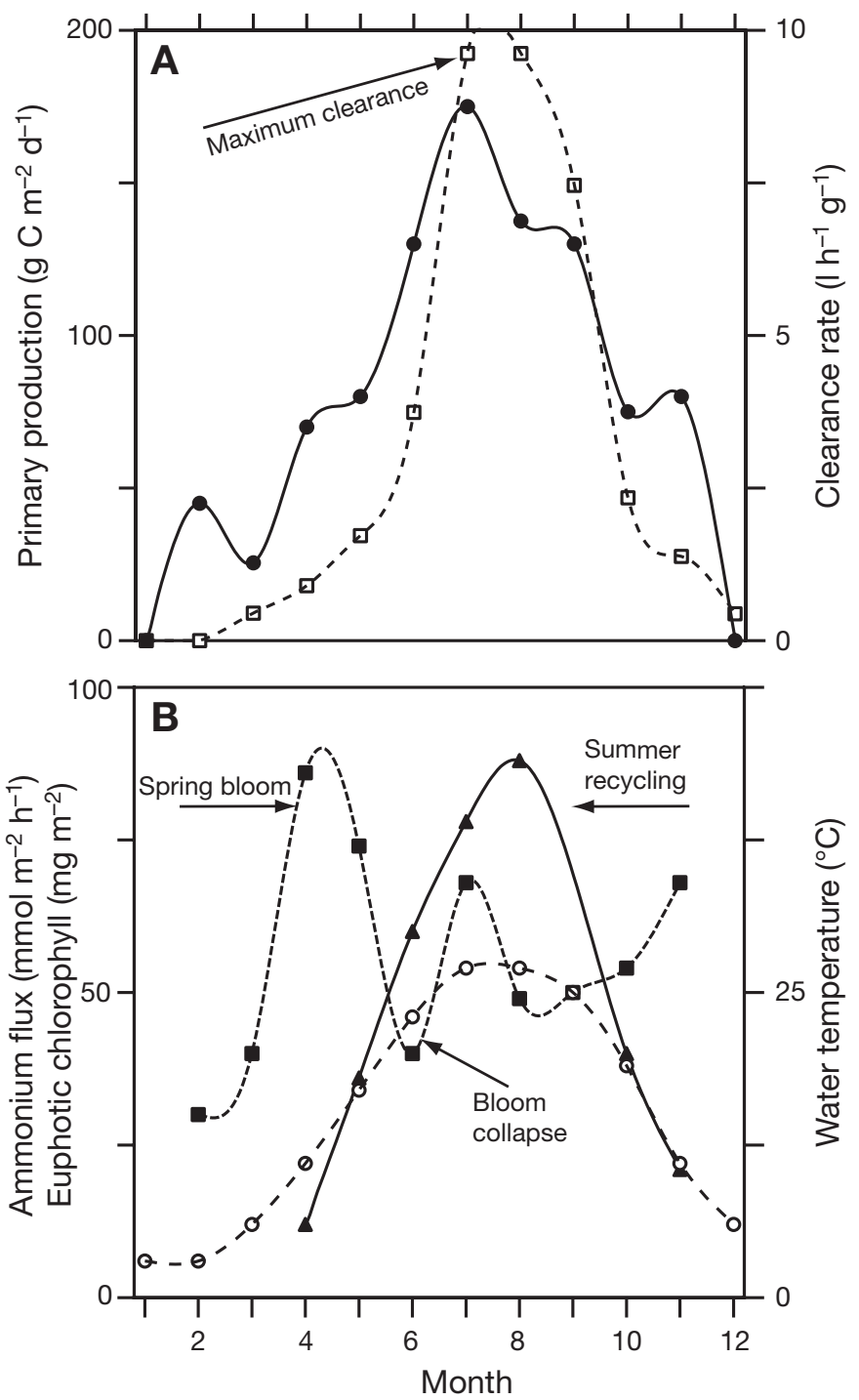

Fig. 2. Multi-year means of annual cycles of phytoplankton production, suspension-feeding, and ammonium regeneration in Chesapeake Bay. (A) Maximum clearance by filterfeeders $(\square)$ and maximum phytoplankton production $(\mathbf{O})$ in summer. (B) Euphotic zone chlorophyll (ם) peaks during the spring bloom, with a lesser peak coinciding with maximum primary production and maximum top-down control in summer; regeneration of ammonium ( $\mathbf{\Delta})$ from collapse of spring bloom, as well as from ongoing production and its utilization, peaks in summer, coincident with maximum primary production and maximum temperature $(\mathrm{O})$. Primary production and euphotic zone chlorophyll from Harding et al. (2002); water clearance rate by oysters Crassostrea virginica from Newell et al. (2005); ammonium flux from Kemp \& Boynton (1992)

\section{Present and former suspension-feeders}

As Gerritsen et al. (1994) pointed out, clearance of water in Chesapeake Bay is not by oysters alone. When the suspension-feeding guild as a whole is enumerated, including worms, barnacles, tunicates, cnidari- ans, and echinoderms, its biomass significantly exceeds that of molluscs and it is resistant to transitory episodes of hypoxia during summer (Sagasti et al. 2000, Schaffner \& Thompson 2002). Hypoxia does not occur during early spring, which is the critical time for controlling blooms. One polychaete species, Chaetopterus variopedatus, has a significant filtration rate in the lower bay (Thompson \& Schaffner 2001), and even though data on the abundance of epifauna in Chesapeake Bay are limited, a more complete inventory of filter-feeding biomass suggests present-day community filtering rates that equal or exceed Newell's (1988) original estimate of water clearance by pre-colonial oysters (Schaffner \& Thompson 2002). The mean filtering rate of suspension feeders $\mathrm{g}^{-1}$ dry weight (at optimal temperatures) for 44 species, from sponges to ascidians, is $7.8 \mathrm{l} \mathrm{g}^{-1} \mathrm{~h}^{-1}(\mathrm{SE} \pm 0.5$; data from Hily 1991, Dame et al. 2001, Hughes 2001). The estimate of total filter-feeding biomass by Schaffner \& Thompson (2002) suggests that it should process a volume of water at least comparable to that of the precolonial oyster reefs (17 $\mathrm{g}$ for pre-colonial oysters vs. $18 \mathrm{~g}$ for present-day suspension-feeding benthic fauna). This estimate does not include filter-feeding epifauna (Sagasti et al. 2000). In current research on the Chesapeake Bay ecosystem, the benthic biomass is estimated to be a 1.3 power function of primary production (Hagy 2000, Schaffner et al. 2002). In spite of the loss of oysters, the biomass of the total filter-feeding guild has probably increased in response to increasing eutrophication of the bay, even taking into consideration the effects of periodic hypoxia on those communities.

Although our estimate of the biomass and filtering potential of the suspension-feeding community in Chesapeake Bay exceeds Newell's (1988) estimate of the potential of pre-colonial oysters (Sagasti et al. 2000, Schaffner \& Thompson 2002), it is clearly not controlling present spring blooms. In addition to the constraints of space and temperature, multiplying filtering rates by biomass is not a true indication of community filtering capacity. Water flow past filter-feeding organisms is not always optimal: disturbance by other organisms occurs, excessive sediment interferes with filter efficiency, organisms in close proximity filter the same water repeatedly and, in a stratified estuary, some water is not accessible to the benthos in the short term. A community of benthic suspension feeders in a shallow bay in the Kattegat (not aggregated in reefs) was found to ingest only one-half of its potential (Loo \& Rosenberg 1989). Similar limiting effects are seen in mussel beds (Wildish \& Kristmanson 1997). Benthic suspension feeders reside in a benthic boundary layer of water that limits their access to particles suspended throughout the water column (Wildish \& Kristmanson 
1997). In turbulent flow, they have short-term access to 1-2 $\mathrm{m}$ of the water column (Fréchette et al. 1989), while during periods of laminar flow they may access a layer that is only centimeters thick. Even during turbulent flow, water is being filtered repeatedly (Fréchette \& Bourget 1985, Wildish \& Kristmanson 1997). Kemp \& Boynton (1992) found the response of benthic suspension feeders to food supply to be less in Chesapeake Bay than in most other systems that have been studied, attributing this to the inhibitory effects of summer hypoxia on aerobic benthic organisms. However, many members of the suspension-feeding guild are resilient to all but very persistent hypoxia and flourish in intermediate or moderately hypoxic conditions (Sagasti et al. 2000, Schaffner et al. 2001). While it is not certain that populations of filter-feeding organisms are at an all-time high for the bay as a whole, they may have increased in regions that experience mild or periodic hypoxia. If suspension feeders are food limited, and were originally competing with strategically located oyster reefs, their abundance may have been somewhat less in pre-colonial Chesapeake Bay. The number of epifauna that were dependent on oysters for living space may have been higher than at present (we are not aware of any published data regarding this). We do know that spring blooms were smaller (Cooper 1995), river flow was less, and saline water extended farther up the bay (Mountford 1986).

In contrast to the spring bloom, summer phytoplankton $(80 \%$ nanoplankton consisting of smaller diatoms and other nanophytoplankton, and $20 \%$ picoplankton consisting largely of autotrophic cyanobacteria; McCarthy et al. 1974) appears to be more closely controlled by the combined action of benthic suspension feeders (Gerritsen et al. 1994; their Fig. 9) and zooplankton, including microzooplankton-protozoans, invertebrate larvae, and rotifers (McManus \& Ederington-Cantrell 1992, Gallegos \& Jordan 1997). During summer, microzooplankton also control heterotrophic bacterioplankton, whose numbers, although high, are similar to those in other eutrophic estuaries. Evidence that microzooplankton can reproduce quickly enough to control the smaller autotrophs was given by Yeager et al. (2005), who found summer blooms consisting mostly of the larger $(>20 \mu \mathrm{m})$ autotrophs following a wind-induced pulse of ammonium. Nanophytoplankton and microzooplankton are within the size range of organisms that suspension feeders can filter efficiently (Langdon \& Newell 1990), and macrozooplankton also consume microzooplankton. Nanophytoplankton and microzooplankton are a probable significant source of nutrition for suspension feeders and zooplankton during summer. More significant top-down control during summer does not, of course, have any effect on the intensity of spring blooms.

\section{Cause and cure for blooms}

Studies of the microfossils and geochemistry of cores of Chesapeake Bay sediments give us extensive insight into changes that have occurred in the bay during the past $2700 \mathrm{yr}$ (Bratton et al. 2003). Sediments show a $>150 \%$ increase in algal and bacterial production since pre-colonial times (Zimmerman \& Canuel 2002), with a 35 to $50 \%$ increase in sediment organic carbon between 1934 and 1948 (Zimmerman \& Canuel 2000). Since 1600, biogenic silica flux to sediments, indicative of diatom production, has increased by a factor of 4 to 5 (Colman \& Bratton 2003). This evidence, as well as that from studies of changes in recent decades, suggests that phytoplankton blooms in Chesapeake Bay are nutrient-driven and have increased with nutrient loading (Malone et al. 1988, Glibert et al. 1995, Harding \& Perry 1997, D'Elia et al. 2003, Kemp et al. 2005, Adolf et al. 2006).

The large year-to-year variation in the extent of spring blooms is related to winter-spring river flow and its inputs of $\mathrm{N}, \mathrm{P}$, and $\mathrm{Si}$, plus strong stratification of the bay by freshwater in high-flow years that stabilizes blooms in the euphotic layer. Interannual variation in flow is driven by regional and global climatic cycles (Malone et al. 1986, Kemp \& Boynton 1992, Malone 1992, Kemp et al. 1997, Acker et al. 2005). The annual timeline of events related to phytoplankton blooms and hypoxia in Chesapeake Bay shows that the greatest accumulation of phytoplankton occurs during the spring bloom (Fig. 2). Years with high river flow have the largest spring blooms and the greatest summer hypoxia (Harding \& Perry 1997, Hagy et al. 2004). Once any essential nutrient element $(\mathrm{N}, \mathrm{P}$, or $\mathrm{Si})$ becomes limiting, the spring bloom, dominated by diatoms, collapses and disappears from the water rapidly (Harding \& Perry 1997, Hagy et al. 2005). Summer hypoxia in Chesapeake Bay is initiated by microbial utilization of the uneaten part of the spring phytoplankton bloom that is concentrated on or near the bottom of the stratified main stem during April and May by the estuarine counter-current (Roden et al. 1995). A lesser peak in chlorophyll occurs in summer (Fig. 2), supported by nutrients (especially ammonium) regenerated microbially during summer from the remains of the spring bloom (Kemp \& Boynton 1992, Glibert et al. 1995) and dispersed by oscillations of the pycnocline (Malone et al. 1986). During summer, however, despite continuing high rates of primary production, chlorophyll concentrations (i.e. phytoplankton populations) remain lower than in spring, implying more top-down control at this time of year (Malone 1992). While the suspension-feeding benthos may experience some inhibition by anoxia at this time, zooplankton, including larval stages of both zooplankton and benthos, are abundant and active. 
Reduction of inputs of nutrients from the watershed is seen as the means by which summer hypoxia of the bay can be reduced (Boesch et al. 2001, D'Elia et al. 2003). Although hypoxia had been noted earlier (Newcombe \& Horne 1938), regular monitoring of nutrient loading, chlorophyll concentrations, and hypoxia did not begin until about 1950 (Fig. 3). By this time, the oyster harvest (our best measure of oyster abundance) had fallen to approximately $30 \%$ of peak rates. Chlorophyll was relatively low in 1950 compared to that in recent years (1975 to 1995), although it was probably already above the pre-colonial baseline (Cooper 1995, Colman \& Bratton 2003). A significant annual summer hypoxic volume was being recorded (1950 to 1995) (Fig. 3). Nitrogen loading has increased since 1950, with the high variance reflecting interaction of loading with river flow. Chlorophyll concentrations have increased less rapidly, but the volume of hypoxic water in the bay during summer continues to increase (Fig. 3). Kemp \& Boynton (1992) suggested that this results from a positive feedback related to inhibition of benthic suspension feeders by hypoxia. In view of the evidence for limited control of phytoplankton by suspension feeders, other possibilities might also be considered, such as multi-year accumulation of organic nitrogen. Although Boynton et al. (1995) suggested that the bay has little nutrient 'memory', the active layer in the sediments contains $>90 \%$ of the nitrogen in the system and would appear to represent at least 5 yr of accumulation. In the exceptional low-flow years of 1988 and 1989, nitrogen loading from rivers was comparable to that in the 1950 s, but chlorophyll con- centrations were higher than in the 1950s (Harding \& Perry 1997). Reversal of trends toward more phytoplankton and hypoxia will probably require long-term reduction in inputs of nitrogen from the watershed and its airshed below some as yet undefined threshold (Malone 1992, Harding \& Perry 1997).

Sediment cores show that detectable eutrophication and hypoxia actually began early in Chesapeake Bay (between 1750 and 1800), coinciding with deforestation and the rise of agriculture in the watershed (Bratton et al. 2003). Organized oyster harvesting began at about the same time, prior to significant depletion of the oyster population. Although most of the Chesapeake oyster population was subsequently lost to fishing and disease, the suspension-feeding guild as a whole may now be as large and as able as it ever has been to control phytoplankton blooms. However, we argue that it does not control blooms now owing to spatial separation of phytoplankton production and its consumers, limited mixing in a large, microtidal estuary, and the constraints of low spring temperatures on filtration rates. The desire for a rapid and inexpensive way to control hypoxia has led to repeated calls for the introduction of non-indigenous species of oysters. This may be desirable for economic, cultural, aesthetic, or other reasons (as it has been on the west coast of North America and in many estuaries of Europe), but it seems doubtful that their presence will moderate spring phytoplankton blooms or hypoxia significantly in Chesapeake Bay. In their revision of the keystone species concept, de Ruiter et al. (2005) see interactive feeding guilds, rather than single species, as influential in

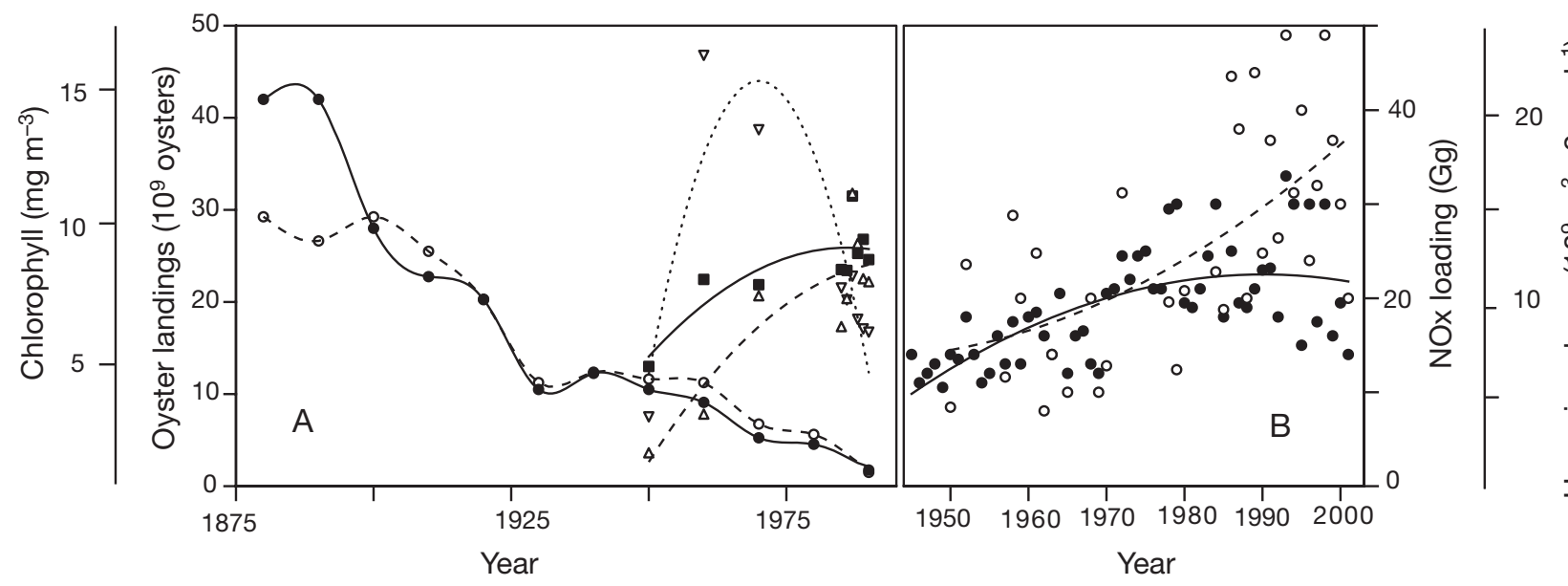

Fig. 3. A 120-year timeline of changes in Chesapeake Bay showing depletion of oysters Crassostrea virginica before increase in phytoplankton chlorophyll. (A) Annual Chesapeake oyster landings, 1875 to 1996, in Maryland (O) and Virginia (•) (from MacKenzie 1997); also shown are mean chlorophyll concentrations in lower ( $\nabla$, dotted line), middle ( $\mathbf{\square}$, continuous line), and upper $(\Delta$, dashed line) segments of the bay (from Harding 1994 and Harding \& Perry 1997). (B) January to May nitrate + nitrite loading (•, continuous line) (from Hagy et al. 2004) and summer hypoxic volume (O, dashed line) (from Hagy et al. 2004). Oyster landings are officially recorded as 'bushels', whereby a Maryland oyster bushel is legally defined as 2800.7 cubic inches, or 350 oysters of $76 \mathrm{~mm}$ each, a Virginia bushel is 3003.9 cubic inches, or 375 oysters of $76 \mathrm{~mm}$ each. Landings shown here as numbers of $76 \mathrm{~mm}$ oysters 
the food web. In Chesapeake Bay, the abundance of individual species within the suspension-feeding guild may have changed, owing to human or natural predation or to other changes in the system, but the collective biomass is probably limited by food supply.

Because of the multiple factors involved, including nutrient loading, the size and morphology of estuaries, the extent and location of filter-feeding populations of plankton and benthos, and the effects of tidal amplitude and river flow on mixing estuarine water, sweeping generalizations about the effect of any single variable across all estuaries are problematic. For example, Monbet (1992) found that in most cases phytoplankton were more abundant in microtidal than macrotidal estuaries but, because of other factors, extreme outliers occurred. The macrotidal Tagus estuary behaved like a microtidal estuary because of its morphology, and the microtidal Hudson estuary fell within the range of macrotidal estuaries. We should be wary of generalizations about the effect of suspension-feeding benthos on phytoplankton without due consideration of estuarine size, circulation patterns, and morphology, as well as the other factors that may regulate community filtering rates.

Acknowledgements. We thank L. W. Harding Jr., A. F. Holland, J. G. Kramer, J. S. Levinton, S. V. Smith, and 2 anonymous reviewers for critical reviews of the manuscript at various stages in its development. Portions of this research by L.C.S. were supported by the Office of Naval Research, Harbor Processes Program (N00014-93-1-098) and the Virginia Institute of Marine Science. L.C.S. also acknowledges numerous students who assisted the fieldwork as part of the Research Experience for Undergraduates Program at VIMS (NSF grant OCE-0244039 to VIMS)

\section{LITERATURE CITED}

Acker JG, Harding LW, Leptoukh G, Zhu T, Shen S (2005) Remotely-sensed chlorophyll $a$ at the Chesapeake Bay mouth is correlated with annual freshwater flow to Chesapeake Bay. Geophys Res Lett 32:LO5601, doi: 10.1029/ 2004Gl021852

Adolf JE, Yeager CL, Miller WD, Mallonee ME, Harding LW (2006) Environmental forcing of phytoplankton floral composition, biomass, and primary productivity in Chesapeake Bay, USA. Estuar Coast Shelf Sci 67:108-122

Boesch DF, Brinsfield RB, Magnien RE (2001) Chesapeake Bay eutrophication: scientific understanding, ecosystem restoration, and challenges for agriculture. J Environ Qual 30:303-320

Boynton WR, Garber JH, Summers R, Kemp WM (1995) Inputs, transformations, and transport of nitrogen and phosphorus in Chesapeake Bay and selected tributaries. Estuaries 18:285-314

Bratton JF, Colman SM, Seal RR II (2003) Eutrophication and carbon sources in Chesapeake Bay over the last 2700 yr: human impacts in context. Geochim Cosmochim Acta 67: 3385-3402

Cloern JE (1982) Does the benthos control phytoplankton blooms in South San Francisco Bay? Mar Ecol Prog Ser 9: 191-202

Cloern JE (1996) Phytoplankton bloom dynamics in coastal ecosystems: a review with some general lessons from sustained investigations of South San Francisco Bay, California. Rev Geophys 34:127-168

Cohen RRH, Dresler PV, Philips EJP, Cory RL (1984) The effect of the asiatic clam, Corbicula fluminea, on phytoplankton of the Potomac River. Limnol Oceanogr 29:170-180

Colman SM, Bratton JF (2003) Anthropogenically induced changes in sediment and biogenic silica fluxes in Chesapeake Bay. Geology 31:71-74

Cooper SR (1995) Chesapeake Bay historical land use: impact on water quality and diatom communities. Ecol Appl 5: 703-723

Dame RF, Bushek D, Prins T (2001) Benthic suspension feeders as determinants of ecosystem structure and function in shallow coastal waters. In: Reise K (ed) Ecological comparisons of sedimentary shores, Springer-Verlag, Berlin, p 11-37

D'Elia CF, Boynton WR, Sanders JG (2003) A watershed perspective on nutrient enrichment, science, and policy in the Patuxent River, Maryland: 1960-2000. Estuaries 26: 171-185

de Ruiter PC, Wolters V, Moore JC, Winemiller KO (2005) Food web ecology: playing jenga and beyond. Science 309:68-71

Fréchette M, Bourget E (1985) Food-limited growth of Mytilus edulis L. in relation to the benthic boundary layer. Can J Fish Aquat Sci 42:1166-1170

Fréchette M, Butman CA, Geyer WR (1989) The importance of boundary layer flows in supplying phytoplankton to the benthic suspension feeder Mytilus edulis L. Limnol Oceanogr 34:19-36

Gallegos CL, Jordan TE (1997) Seasonal progression of factors limiting phytoplankton pigment biomass in the Rhode River estuary, Maryland (USA). I. Controls on phytoplankton growth. Mar Ecol Prog Ser 161:185-198

Gerritsen J, Holland AF, Irvine DE (1994) Suspension-feeding bivalves and the fate of primary production: an estuarine model applied to Chesapeake Bay. Estuaries 17:403-416

Glibert PM, Conley DJ, Fisher TR, Harding LR Jr, Malone TC (1995) Dynamics of the 1990 winter/spring bloom in Chesapeake Bay. Mar Ecol Prog Ser 122:27-43

Hagy JD (2000) Eutrophication, hypoxia, and trophic transfer efficiency in Chesapeake Bay. Chapter 4. Patterns of macrobenthic biomass and community bioenergetics in Chesapeake Bay during summer in relation to habitat quality and organic carbon supply. Doctoral dissertation, University of Maryland, College Park, MD

Hagy JD III, Boynton WR, Keef KV, Wood KV (2004) Hypoxia in Chesapeake Bay, 1950-2001: long-term change in relation to nutrient loading and river flow. Estuaries 27:634-658

Hagy JD III, Boynton WR, Jasinski DA (2005) Modelling phytoplankton deposition to Chesapeake Bay sediments during winter-spring: interannual variability in relation to river flow. Estuar Coast Shelf Sci 62:25-40

Harding LW Jr (1994) Long-term trends in the distribution of phytoplankton in Chesapeake Bay: roles of light, nutrients and streamflow. Mar Ecol Prog Ser 104:267-291

Harding LW Jr, Perry ES (1997) Long-term increase of phytoplankton biomass in Chesapeake Bay, 1950-1994. Mar Ecol Prog Ser 137:39-52

Harding LW Jr, Mallonee ME, Perry ES (2002) Toward a predictive understanding of primary productivity in a temperate, partially stratified estuary. Estuar Coast Shelf Sci 55: $437-463$

Hily C (1991) Is the activity of benthic suspension feeders a 
factor controlling water quality in the Bay of Brest? Mar Ecol Prog Ser 69:179-188

Hughes D (2001) A review of biological filtration by marine invertebrates. SAMS Ann Rep Tech Annex. Available at: www.sams.ac.uk/biofaqs.litrev_01.pdf

Hood RR, Boicourt WC (2005) CICEET Progress report, A community model for Chesapeake Bay. Available at: http://ciceet.unh.edu/progessreports/2005/3_2005/mL2002/

Jackson JBC, Kirby MX, Berger WH, Bjorndal KA and 15 others (2001) Historical overfishing and the recent collapse of coastal ecosystems. Science 293:629-637

Jassby AD, Koseff JR, Monismith SG (1996) Processes underlying phytoplankton variability in San Francisco Bay. In: Hollibaugh JT (ed) San Francisco Bay: the ecosystem. American Association for the Advancement of Science, Pacific Division, San Francisco, CA, p 325-349

Jordan SJ (1987) Sedimentation and remineralization associated with biodeposition by the American oyster Crassostrea virginica (Gmelin). Doctoral dissertation, University of Maryland, College Park, MD

Jørgensen CB, Larsen PS, Riisgaard HU (1990) Effects of temperature on the mussel pump. Mar Ecol Prog Ser 64:89-97

Kemp WM, Boynton WR (1992) Benthic-pelagic interactions: nutrient and oxygen dynamics. In: Smith DE, Leffler M, Mackiernan G (eds) Oyygen dynamics in the Chesapeake Bay. A synthesis of research. Maryland Sea Grant College, College Park, MD, p 149-221

Kemp WM, Smith EM, Marvin-DiPasquale M, Boynton WR (1997) Organic carbon balance and net ecosystem metabolism in Chesapeake Bay. Mar Ecol Prog Ser 150: 229-248

Kemp WM, Boynton, WR, Adolf JE, Boesch DF and 14 others (2005) Eutrophication of Chesapeake Bay: historical trends and ecological interactions. Mar Ecol Prog Ser 303: $1-29$

Langdon CJ, Newell RIE (1990) Utilization of detritus and bacteria as food sources by two bivalve suspension feeders, the oyster Crassostrea virginica and the mussel Geukensia demissa. Mar Ecol Prog Ser 58:299-310

Loo LO, Rosenberg R (1989) Bivalve suspension-feeding dynamics and benthic-pelagic coupling in an eutrophicated marine bay. J Exp Mar Biol Ecol 130:253-276

Loosanoff V (1958) Some aspects of the behavior of oysters at different temperatures. Biol Bull (Woods Hole) 114:57-70

MacKenzie CL Jr (1997) The molluscan fisheries of Chesapeake Bay. In: MacKenzie CL Jr, Burrell VG Jr, Rosenfield A, Hobart WL (eds) The history, present condition, and future of the molluscan fisheries of North and Central America and Europe. V. 1. Atlantic and Gulf coasts. National Marine Fisheries Service Rep No. 127, Washington, DC, p 141-170

Malone TC (1992) Effects of water column processes on dissolved oxygen, nutrients, phytoplankton and zooplankton. In: Smith DE, Leffler M, Mackiernan G (eds) Oxygen dynamics in the Chesapeake Bay. A synthesis of recent research. Maryland Sea Grant College, College Park, MD, p 61-112

Malone TC, Kemp WM, Ducklow HW, Boynton R, Tuttle JN, Jonas B (1986) Lateral variation in the production and fate of phytoplankton in a partially stratified estuary. Mar Ecol Prog Ser 32:149-160

Malone TC, Crocker LH, Pike SE, Wendler BW (1988) Influences of river flow on the dynamics of phytoplankton production in a partially stratified estuary. Mar Ecol Prog Ser 48:235-249

McCarthy JJ, Taylor WR, Loftus ME (1974) Significance of nanoplankton in the Chesapeake Bay estuary and problems associated with the measurement of nanoplankton productivity. Mar Biol 24:7-16

McManus GB, Ederington-Cantrell MC (1992) Phytoplankton pigments and growth rates, and microzooplankton grazing in a large temperate estuary. Mar Ecol Prog Ser 87:77-85

Monbet Y (1992) Control of phytoplankton biomass in estuaries: a comparative analysis of microtidal and macrotidal estuaries. Estuaries 15:563-571

Mountford K (1986) Ecological change through history - an introduction. J Wash Acad Sci 76:141-145

Newcombe CL, Horne WA (1938) Oxygen-poor waters of the Chesapeake Bay. Science 88:80-81

Newell RIE (1988) Ecological changes in Chesapeake Bay, are they the result of overharvesting the eastern oyster (Crassostrea virginica)? In: Lynch MP, Krome EC (eds) Understanding the estuary, Publ 129, Chesapeake Research Consortium, Gloucester Point, VA (also available at www.vims.edu/GreyLit/crc129.pdf)

Newell RIE, Fisher TR, Holyoke RR, Cornwell JC (2005) Influence of eastern oysters on nitrogen and phosphorus regeneration in Chesapeake Bay, USA. In: Dame RF, Olenin S (eds) The comparative roles of suspension feeders in ecosystems (NATO ASI Ser Ser 4 Earth Environ Sci). Springer-Verlag, Berlin, p 93-120

Ocean Studies Board, National Research Council (2004) Nonnative oysters in the Chesapeake Bay. National Academy Press, Washington, DC

Paynter K (2003) Oyster restoration and management of the Chesapeake Bay oyster fishery in Maryland. Proc shellfish management workshop: managing shellfish for sustainibility. Available at: www.Loughs-Agency.org/Loughs $\% 20$ Agency\%20shellfish\%20workshop.pdf

Roden EE, Tuttle JH, Boynton WR, Kemp WM (1995) Carbon cycling in mesohaline Chesapeake Bay sediments. 1. Particulate organic carbon deposition rates and mineralization pathways. J Mar Res 53:799-819

Ruesink JL, Lenihan HS, Trimble AC, Heiman KW, Micheli F, Byers JE, Kay MC (2005). Introduction of non-native oysters: ecosystem effects and restoration implications. Annu Rev Ecol Syst 36:643-689

Sagasti AL, Schaffner LC, Duffy JE (2000) Epifaunal communities thrive in an estuary with hypoxic episodes. Estuaries 23:474-487

Schaffner LC, Thompson ML (2002) Clearing the muddy waters: suspension feeders flourish in Chesapeake Bay. Estuarine Research Federation, meeting abstracts. Available at: http://erf.org/usercgi/conference_abstract.pl?conference $=$ erf $2001 \& i d+792$

Schaffner LC, Dellapenna TM, Hinchey EK, Friedrichs CT, Thompson Neubauer M, Smith ME, Kuehl SA (2001) Physical energy regimes, seabed dynamics and organismsediment interactions along an estuarine gradient. In: Aller JY, Woodin SA, Aller RC (eds) Organism-sediment interactions. University of South Carolina Press, Columbia, SC, p 159-179

Schaffner LC, Friedrichs CT, Dauer DM (2002) Review of the benthic process model with recommendations for further modeling efforts. A report from the benthic process model review team. Available at: www.chesapeake.org/ stac/BRT_Final_Report.pdf

Smaal AC, Prins TC (1993) The uptake of organic matter and the release of inorganic nutrients by bivalve suspension feeder beds. In: Dame RF (ed) Bivalve filter feeders in estuarine and coastal processes. Springer-Verlag, Heidelburg, p 273-298

Thompson ML, Schaffner LC (2001) Population biology and 
secondary production of the suspension feeding polychaete Chaetopterus veriopedatus: implications for benthic-pelagic coupling in lower Chesapeake Bay. Limnol Oceanogr 46:1899-1907

Ulanowicz RE, Tuttle JH (1992) The trophic consequences of oyster stock rehabilitation in Chesapeake Bay. Estuaries 15:298-306

Widdows J, Bayne BL (1971) Temperature acclimation of Mytilus edulis with reference to its energy budget. J Mar Biol Assoc UK 51:827-843

Wildish D, Kristmanson D (1997) Benthic suspension feeders

Editorial responsibility: Barry \& Evelyn Sherr (Contributing Editors), Corvallis, Oregon, USA and flow. Cambridge University Press, Cambridge

Yeager CLJ, Harding LW Jr, Mallonee ME (2005) Phytoplankton production, biomass and community structure following a summer nutrient pulse. Aquat Ecol 39:135-149

Zimmerman AR, Canuel EA (2000) A geochemical record of eutriophication and anoxia in Chesapeake Bay sediments: anthropogenic influence on organic matter composition. Mar Chem 69:117-137

Zimmerman AR, Canuel EA (2002) Sediment geochemical records of eutrophication in the mesohaline Chesapeake Bay. Limnol Oceanogr 46:1084-1093

Submitted: January 12, 2006; Accepted: April 18, 2006 Proofs received from author(s): October 5, 2006 